\title{
Taxonomic diversity of macrandrous species of Oedogonium Link ex Hirn (Chlorophyceae: Oedogoniales) with emphasis on ecology from Hooghly, West Bengal
}

\section{Nilu Halder}

Department of Botany. Raja Peary Mohan College. Uttarpara-712258. Hooghly. West Bengal. India. Email: niluhalder1@gmail.com.

\begin{abstract}
The present paper includes detail taxonomic features of nine taxa of Oedogonium Link ex Hirn (Chlorophyceae: Oedogoniales) collected from Hooghly district, West Bengal, India. These taxa are Oedogonium bharuchae N.D. Kamat, Oedogonium cardiacum f. pulchellum Hirn, Oedogonium crispum var. pyriforme (Wittr. ex Hirn) A.K.M.N. Islam et P. Sarma, Oedogonium gunnii Wittr. ex Hirn, Oedogonium khannae f. minus Gonzalves et S.C. Jain, Oedogonium nanum Wittr. ex Hirn, Oedogonium pratense Trans., Oedogonium rivulare A. Br. ex Hirn and Oedogonium vaucheri A. Br. ex Hirn. All those taxa were found to grow epiphytically on the leaves and stems of submerged hydrophytes as filaments in quiet lentic freshwater bodies after the end of rainy season. Twelve limnological parameters like temperature, $\mathrm{pH}, \mathrm{DO}, \mathrm{BOD}, \mathrm{COD}, \mathrm{NO}_{3}-\mathrm{N}, \mathrm{PO}_{4}^{3-}, \mathrm{Cl}^{-}$ , free $\mathrm{CO}_{2}$, TDS, total hardness and turbidity of algal habitats were analyzed and found conducive for their occurrence and growth up to maturity (formation of fertile structures). The result of limnological study also indicated that all these species preferred to grow alkaline $\mathrm{pH}$, less turbid and hard water. Studied limnological parameters recorded as water temperature: $17.5^{\circ} \mathrm{C}-20^{\circ} \mathrm{C}, \mathrm{pH}$ range from 7.1-7.6, high dissolved oxygen (DO) concentration 6.4-7.2 mg.L-1 $\mathrm{L}^{-1}$ BOD values < 20.0 mg. $\mathrm{L}^{-1}$, moderate COD values and lower nutrient levels with other parameters like $\mathrm{Cl}-$, free $\mathrm{CO}_{2}$, TDS, turbidity as 6.8-9.0 NTU and also hard nature of water ranged from 120-204 mg.L-1.
\end{abstract}

Keywords: Macrandrous Oedogonium; Taxonomy; Ecology; Hooghly; West Bengal.
Received April 24, 2018

Accepted

July 9, 2018

Released

August 31, 2018

Full Text Article

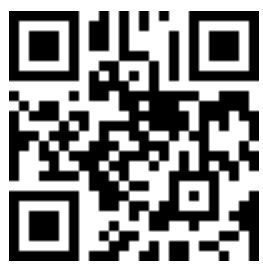

ORCID

(D) 0000-0002-9689-3952 Nilu Halder

\section{Introduction}

Algae have the efficiency to decrease atmospheric $\mathrm{CO}_{2}$ level, pollution and responsible for reduction of more than $40 \%$ of the total global carbon through its fixation by photosynthesis, although majority of carbon fixation done by marine algae (Munir et al., 2015). Thus, they are potential cryptogamic plant for significant decreasing of green house gases which are recently considered as main culprits for global warming and climate change.

Filamentous green algae in the order Oedogoniales of class 
Chlorophyceae constitute an important part of algal communities in freshwater habitats (Halder, 2015a). This order includes only one family Oedogoniaceae which contains three well known algal genera viz. Oedogonium Link ex Hirn, Bulbochaete C. Ag. and Oedocladium Stahl. Nevertheless, their enormous morphological variations and the difficulties to study some micromorphological features have complicated their taxonomic identifications (Cambra and Aboal, 1992). However, freshwater macroalgae particularly the genus Oedogonium have recently been targeted for production of algal biomass due to its high productivity rate and enrichment of bioactive organic compounds (Tonetto et al., 2014) like eicosane, 1-nonadecene, tricosane, heneicosane, nona hexacontanoic acid, butylated hydroxytoluene, nonadecane, 1-docosene and ca. 12.9\% lipids (Adesalu et al., 2016). It is cosmopolitan in distribution and a competitive dominator over other algal species and genera (Lawton et al., 2014). In vitro studies of selected solvent extracts of this genus revealed that it has the capability to show antibacterial, antispasmodic effects i.e. prevent cramp (spasm) of gastrointestinal tract muscle due to possessing novel $\delta$-lactone bioactive molecules (Pérez Gutiérrez et al., 2006) and antifungal (Snehalatha and Rao, 2015) property. Besides these, a species of Oedogonium (O. globosum Nordst.) showed moderate in vitro antioxidant ability against the different solvent extracts and thus could be used as a natural antioxidant (Seal et al., 2014). Sometimes, unicellular to colonial minute epiphytic algae including diatoms are found to grow on the upper surface of the filaments of this genus (Wehr et al., 2015). This green alga is also very common and widespread in Indian subcontinent (southern region of Asia). Few important characteristics of this alga are: i) it is filamentous, unbranched and looks greenish in vegetative condition ii) cells are rectangular or cylindrical, longer than broad and show polarity i.e apex is normally broader than base, uninucleate and bearing ring like apical caps distally iii) chloroplasts reticulate with several pyrenoids. It is abundantly noticed particularly in small water bodies (Pikosz and Messyasz, 2015) or standing aquatic ecosystems like ponds, jheels, paddy fields, ditches, lakes and rarely recorded on the wet soil. It is occasionally observed as free floating form on the upper surface of water, when fruiting structures develop. Size of the vegetative cells, measurement of oogonia and oospores, the decoration of the oospore wall and the location, shape and size of the dwarf male filament (nannandrium) are considered as important differentiating/specific characteristics to identify species of this genus. Some species of Oedogonium are also pollution tolerant (Anand and Jitendra, 2006). Currently, over 450 species have been documented worldwide (Novis, 2003). Recently, the chloroplast genome analysis of this alga exhibited a close alliance with the order Chaetophorales (Brouard et al., 2008).

Many environmental factors like light intensity, temperature, $\mathrm{pH}$, host plant, depth of water bodies, nutrient status and other limnological parameters affect the distribution, diversity and abundance of aquatic algal flora. Hence, study of maximum number of physicochemical properties of water in any aquatic system is essential to know the pollution level, trophic status and for assessing water quality. Actually, various chemical reactions/oxidation-reduction processes play an important role in governing most of the biochemical and microbial activities and also maintaining sustainability or congenial environmental condition in water. Any way, if aquatic ecosystem or environment degrades, then eutrophication and overall loss of biodiversity result.

The algal floristic study explores biodiversity of species, genera etc. (Halder, 2016a) in a particular habitat, 
ecosystem or geographical region (Sinha et al., 2016). Based on phenotypic characters, the taxonomy and morphology of this genus were studied after 1950 by Gonzalves and Jain (1968), Kamat $(1974,76)$, Asthekar and Kamat (1978), Dhande and Jawale (2006), Patil et al., (2015), Jitendra and Anand (2016) and Phadnis and Iyer (2016) from Maharashtra; Singh (1938), Venkataraman (1959), Pandey (1965), Khan (1985), Habib and Pandey (1990) and Misra et al., (2002) from Uttar Pradesh; Parukutty (1939) and Lakshminarayan (1965) from Kamrup in Assam; Gupta (1950) from Khajiar Champa area and Kamat (1968) from Simla in Himachal Pradesh; Venkataraman and Natarajan (1960) from Kerala; Gonzalves and Sonnad (1961), Bharati and Pai (1972) from Karnataka; Bharadwaja (1963) from Manipur; Goyal (1964), Kamat (1967) and Yadava and Bharadwaja (1979) from Rajasthan; Subba Raju (1986) form from Andha Pradesh; Kamat (1962) and Patel (1990) from Gujarat; Saha (1985), Mahato (1999) and Mahato et al., (2006) from Bihar as well as Mahato and Mahato (2000) from Jharkhand. So, a continuous progress in taxonomic research works on Oedogoniales has been noticed from India.

However, no information is available from Hooghly district in West Bengal, India except a single report (Halder and Sinha, 2015). Thus, an attempt has been made by the author to explore floristic account of the genus with ecological information.

\section{Materials and methods}

\section{Sample collection}

Hooghly district $\left(20^{\circ} 01^{\prime} 32^{\prime \prime}\right.$ $23^{\circ} 30^{\prime} 20^{\prime \prime} \mathrm{N}$ and $80^{\circ} 30^{\prime} \quad 15^{\prime \prime}$ $87^{\circ} 30^{\prime} 20^{\prime \prime}$ E) of West Bengal (Halder, 2017a) covers a total area of about $3,149 \mathrm{~km}^{2}$ and occupies different types of water resources and thus, supports growth of different types algae (Halder and Sinha, 2016). The algal specimens were collected from different ecological habitats including ponds, ditch, marshy land and paddy field wetland located at different places (Chinsurah, Madhusudanpur, Somra Bazar, Guptipara, Khamargachi, Balarambati, Khanyan and Diara) of this district (Figure 1).

\section{Microscopy}

Microscopic examination of the nine species of the genus was carried out under Olympus microscope (ModelCH20i). Microphotographs were taken using Canon Power Shot A480 camera. The samples were preserved by $4 \%$ formalin and the voucher specimens were deposited in the Departmental Herbarium of R. P. M. College, Uttarpara, Hooghly, West Bengal.

\section{Identification}

It was carried out with the aid of monographs and scientific literatures (Prescott, 1962; Gonzalves and Jain, 1968; Islam and Sarma, 1976; Gonzalves, 1981).

\section{Water analysis}

The temperature $\left({ }^{\circ} \mathrm{C}\right)$ and $\mathrm{pH}$ of freshwater were recorded at the collection sites with the help of mercury thermometers and portable $\mathrm{pH}$ meter. The other limnological parameters such as DO, $\mathrm{BOD}, \mathrm{COD}, \mathrm{NO}_{3}-\mathrm{N}, \mathrm{PO}_{4}{ }^{3-}, \mathrm{Cl}$, free $\mathrm{CO}_{2}$, TDS, TH and turbidity of water were estimated in the laboratory following the standard method (APHA, 2005). DO by Winkler method with Rideal-Stewart modification, 5-day BOD as well as COD test by titrimetric method, nitratenitrogen and phosphate were determined by brucine method and stannous chloride method using a UV-Vis spectrophotometer (CECIL CE 7200), 
$\mathrm{Cl}^{-}$by argentometric method using same spectrophotometer and free $\mathrm{CO}_{2}$ of water was measured following acid-base titrimetry using phenolphthalein as indicator. TDS i.e filterable residue remains after evaporation and drying at
$180{ }^{\circ} \mathrm{C}$ was measured outlined in the above standard method. Total hardness was determined by EDTA titration method. A nephelometer (model CL-52D) was used to measure water turbidity.

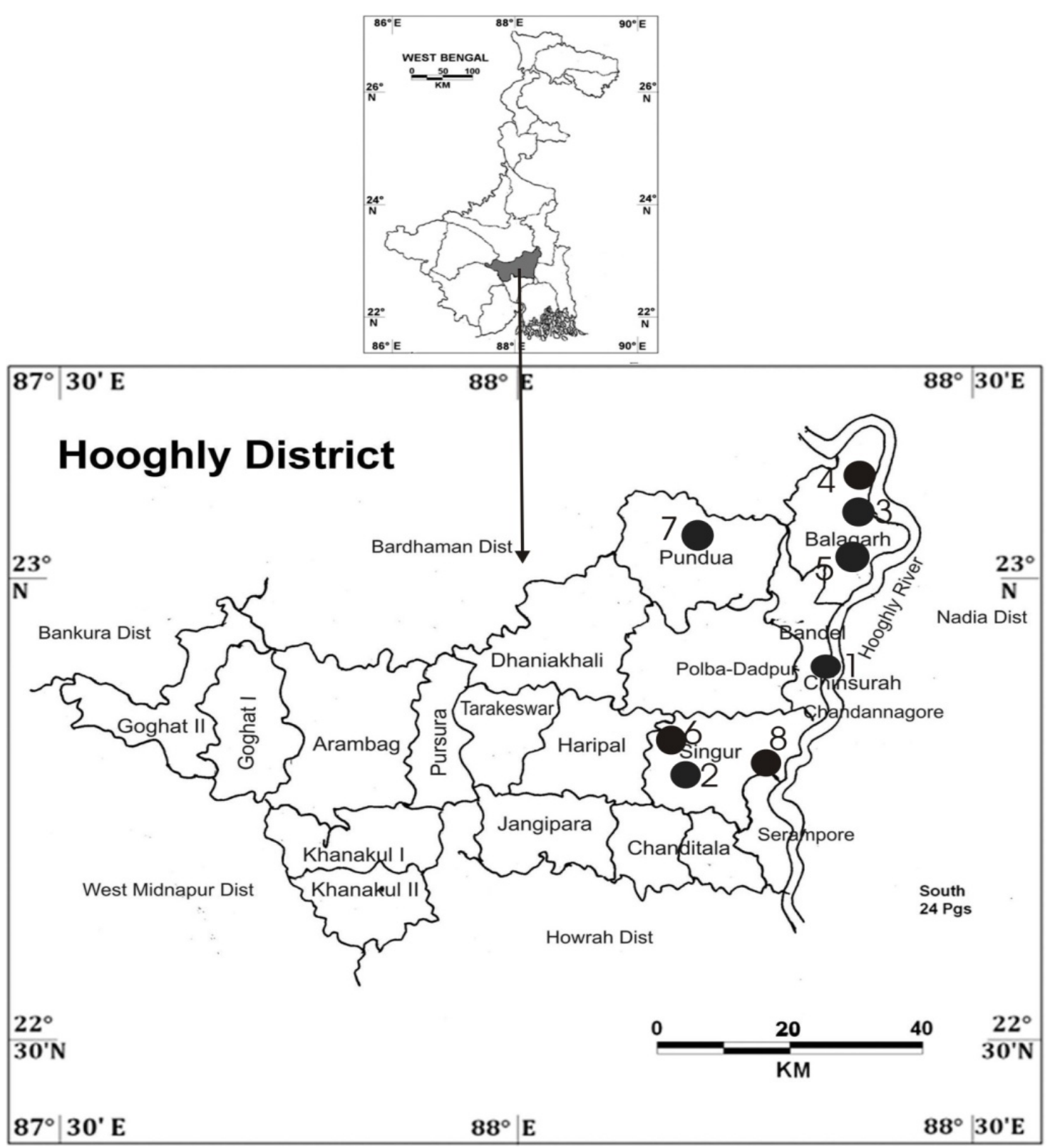

Figure 1. Algal sampling sites ( $)$ in Hooghly district, West Bengal, India. 
Table 1. Characteristics of sampling sites with algal species and collection time.

\begin{tabular}{|c|c|c|c|c|c|c|}
\hline & Sampling sites & $\begin{array}{l}\text { Site } \\
\text { code }\end{array}$ & Growing species & $\begin{array}{c}\text { Geographical } \\
\text { coordinates }\end{array}$ & $\begin{array}{c}\text { Site } \\
\text { characteristics } \\
\end{array}$ & Collection months \\
\hline 1 & Chinsurah & $\bar{A}$ & O. bharuchae & $\begin{array}{l}22^{\circ} .88^{\prime} \mathrm{N} \\
88^{\circ} .39^{\prime} \mathrm{E}\end{array}$ & $\begin{array}{l}\text { Agricultural } \\
\text { pond }\end{array}$ & $\begin{array}{l}\text { October } \\
\text { (post-monsoon) }\end{array}$ \\
\hline 2 & Madhusudanpur & B & $\begin{array}{l}\text { O. cardiacum f. } \\
\text { pulchellum }\end{array}$ & $\begin{array}{l}23^{\circ} .01^{\prime} \mathrm{N} \\
88^{\circ} .40^{\prime} \mathrm{E}\end{array}$ & Ditch & $\begin{array}{l}\text { November } \\
\text { (winter) }\end{array}$ \\
\hline 3 & Somra Bazar & $\mathrm{C}$ & $\begin{array}{l}\text { O. crispum var. } \\
\text { pyriforme }\end{array}$ & $\begin{array}{l}23^{\circ} .13^{\prime} \mathrm{N}, \\
88^{\circ} .43^{\prime} \mathrm{E}\end{array}$ & Marshy land & $\begin{array}{l}\text { November } \\
\text { (winter) }\end{array}$ \\
\hline 4 & Guptipara & D & O. gunnii & $\begin{array}{l}23^{\circ} .20^{\prime} \mathrm{N} \\
88^{\circ} .40^{\prime} \mathrm{E}\end{array}$ & Fish pond & $\begin{array}{l}\text { October } \\
\text { (post-monsoon) }\end{array}$ \\
\hline 5 & Khamargachi & E & $\begin{array}{l}\text { O. khannae } \\
\text { minus }\end{array}$ & $\begin{array}{l}23^{\circ} .06^{\prime} \mathrm{N} \\
88^{\circ} .43^{\prime} \mathrm{E}\end{array}$ & Field pond & December (winter) \\
\hline 6 & Balarambati & $\mathrm{F}$ & O. nanum & $\begin{array}{l}22^{\circ} .81^{\prime} \mathrm{N} \\
88^{\circ} .21^{\prime} \mathrm{E}\end{array}$ & Field pond & December (winter) \\
\hline 7 & Khanyan & G & O. pratense & $\begin{array}{l}23^{\circ} .04^{\prime} \mathrm{N} \\
88^{\circ} .32^{\prime} \mathrm{E}\end{array}$ & $\begin{array}{l}\text { Paddy } \\
\text { wetland }\end{array}$ & $\begin{array}{l}\text { September } \\
\text { (post-monsoon) }\end{array}$ \\
\hline 8 & Diara & $\mathrm{H}$ & O. rivulare & $\begin{array}{l}22^{\circ} .79^{\prime} \mathrm{N}, \\
88.26^{\prime} \mathrm{E}\end{array}$ & Bathing pond & December (winter) \\
\hline 9. & Diara & $\mathrm{H}$ & O. vaucheri & $\begin{array}{l}22^{\circ} .79^{\prime} \mathrm{N} \\
88.26^{\prime} \mathrm{E}\end{array}$ & Same as site $H$ & December (winter) \\
\hline
\end{tabular}

\section{Results}

Nine taxa of the genus were recorded in this study and reported here as new for Hooghly district in West
Bengal, India. The fertile specimens of this genus had been collected from last week of September to December, 2016.

\section{Systematic position}

Class: Chlorophyceae

Order: Oedogoniales

Family: Oedogoniaceae (Fritsch, 1935)

Genus: Oedogonium Link

\section{Key to the species}

1. Plant monooecious

1'. Plant dioecious

2. Oogonium poriferous

O. vaucheri

2'. Oogonium operculate

3. Division of operculum superior

O.crispum var. pyriforme

3'. Division median O. gunnii

4. Oogonium poriferous 5

4'. Oogonium operculate 6

5. Pore supramedian O. cardiacum f. pulchellum

5'. Pore superior O. rivulare

6. Division operculum superior

6'. Division median 
7. Vegetative cells larger (17.0-22.0 $\mu \mathrm{m}$ broad, 60.0-80.0 $\mu \mathrm{m}$ long); oogonium

broadly oval or spherical-ellipsoid O. bharuchae

7'. Vegetative cells smaller (6.0-10.0 $\mu \mathrm{m}$ broad, 15.0-33.0 $\mu \mathrm{m}$ long) and irregular in size; oogonium ovoid or ellipsoid O. nanum

8. Oogonia in series up to 7 and smaller (19.5-21.0 $\mu \mathrm{m}$ broad and 17.5-23.0 $\mu \mathrm{m}$ long) O. khannae f. minus 8'. Oogonium not in series and larger $(42.0-44.0 \mu \mathrm{m}$ broad and 42.0-44.0 $\mu \mathrm{m}$ long) O. pretense

1. Oedogonium bharuchae N. D. Kamat in Rev. Algol. 6: 218, figs. 4-5, 1962; Gonzalves, Oedogoniales 242-43, fig. 9.122, 1981 (Plate 1. Fig. 1).

Description: Plant macrandrous, dioecious, filamentous, unbranched; vegetative cell distinctly capitates; female filament 17.0-22.0 $\mu \mathrm{m}$ broad, 60.0-80.0 $\mu \mathrm{m}$ long; chloroplast reticulate with pyrenoids; oogonium broadly ellipsoidal, oval or spherical-ellipsoidal, 50.0-55.0 $\mu \mathrm{m}$ broad, 52.0-61.0 $\mu \mathrm{m}$ long; operculate, division supreme; oosopre shape identical to oogonium and filling the oogonium; $48.0-52.0 \mu \mathrm{m}$ broad, 50.0$58.0 \mu \mathrm{m}$ long; spore wall brown, smooth and thick; antheridia 4-8, seriate; 16.0$20.0 \mu \mathrm{m}$ broad, 20.0-25.0 $\mu \mathrm{m}$ long; spermatozoid single (absent in figure).

Habitat: Attached on aquatic weeds in agricultural pond located at Chinsurah (Site-A).

Date of collection: 05.10.2016; Collection number: NH Oedo. 02

Known distribution: India: Gujarat (Kamat, 1962), West Bengal (Sahoo, 2006).

Outside of India: There are no reports of distribution of this species in abroad.

Comment: It's look like $O$. obtruncatum Wittr. ex Hirn regarding shape of oogonium and supreme position of operculum but the present species is macrandrous rather than nannandrous. The above taxon seems to be somewhat similar to the $O$. thanaense Gonzalves et Jain in few characters like both are macrandrous, heterothallic, oogonium is operculate and division is supreme but in the described specimen, vegetative cells of female filament are slight broader, short and has comparatively smaller oogonium than $O$. thanaense Gonzalves et Jain. This is probably the second time record of this species from West Bengal.

2. Oedogonium cardiacum f. pulchellum Hirn in Acta Soc. Sc. Fenn. 27: 86, pl. 3, fig. 20, 1900; Vesiculifera pulchella Hassall, 1845 (Plate 1. Fig. 2).

Description: Plant macrandrous, heterothallic, filamentous and unbranched; light greenish; basal cell elongates; female vegetative cell cylindrical, 25.0-36.0 $\mu \mathrm{m}$ broad and 54.0$60.0 \mu \mathrm{m}$ long, terminal cell obtuse; chloroplast parietal, reticulate with several pyrenoids; nucleus one; oogonium solitary, usually one, subcordiform-globose, 58.0-65.0 $\mu \mathrm{m}$ broad and 68.0-72.0 $\mu \mathrm{m}$ long; poriferous, pore supramedian; oospore usually globose and not filling the oogonium, 56.0-60.0 $\mu \mathrm{m}$ broad and 56.0-60.0 $\mu \mathrm{m}$ long; spore wall smooth; terminal cell apically obtuse; division horizontal; antheridia not found in this specimen.

Habitat: It was found attached with stems on Ipomoea aquatica Forssk. in a ditch at Madhusudanpur (Site-B).

Date of collection: 07.11.2016; Collection number: NH Oedo. 04

Known distribution: India: There is no report of this forma from this country.

Outside of India: Europe in Britain, U.S.A. in Gallia (Hirn, 1900); Bangladesh (Islam, 1976). 
Comment: This species can be resembled with $O$. vaucheri A. Br. ex Hirn and $O$. sociale Wittr. ex Hirn regarding shape of oogonium; oospores not filling oogonium, poriferous nature of oogonium and oospore wall smooth but it is different from those two species in respect of pore position and smaller vegetative cell. This forma is probably first time report from India.

3 Oedogonium crispum var. pyriforme (Wittr. ex Hirn) A. K. M. N. Islam et P. Sarma in Nov. Hedw. 27: 436, 1976; Oedogonium pyriforme Wittr. ex Hirn, 1900 (Plate 1. Fig. 3).

Description: Plant macrandrous, monoecious, filamentous, unbranched, brownish-green, attached to substratum by basal holdfast cell; vegetative cell uninucleate, cylindrical/rectangular; 16.5-17.5 $\mu \mathrm{m}$ broad and 25.5-50.5 $\mu \mathrm{m}$ long; chloroplast reticulate with several pyrenoids; oogonium one, pyriform or pyriform-globose shaped, operculate, division superior, 34.0-38.0 $\mu \mathrm{m}$ broad and 36.0-40.0 $\mu \mathrm{m}$ long; oospore brownish, shape same as oogonium, filling or not the oogonium; oospore 30.0-32.0 $\mu \mathrm{m}$ broad and 34.0-38.0 $\mu \mathrm{m}$ long; spore wall brown, smooth and thick; antheridium one to two, subepigynous, $12.0-16.0 \mu \mathrm{m}$ broad and 5.0$7.0 \mu \mathrm{m}$ long.

Habitat: It was found attached on aquatic grass in a marshy land at Somra Bazar (Site-C).

Date of collection: 22.11.2016; Collection number: NH Oedo. 05

Known distribution: India: Previously, there is no report of this variety.

Outside of India: Bangladesh in Dhaka (Islam and Sarma, 1976). North America: Great Lakes (Prescott, 1962); Australia: Tasmania (Day et al., 1995; Guiry and Guiry, 2018).

Comment: It showed similarity with $O$. oblongum Wittr. ex Hirn in respect of shape of oogonium as it is pyriform or ob-ovoid but the present specimen showed few deviations from the former regarding larger breadth of vegetative cells (> 3.5-6.5 $\mu \mathrm{m}$ ) and oogonium size (> 15.0-17.0 $\mu \mathrm{m})$. In this specimen, the oogonium and oospore were found pyriform and antheridium mostly hypogynous. So, it differs from $O$. crispum var. pithophorae (Wittr. ex Hirn) Islam et Sarma and is treated as 0 . crispum var. pyriforme (Wittr. ex Hirn) Islam et Sarma. Probably, the variety is first time report from India.

4. Oedogonium gunnii Wittr. ex Hirn; Wittr. in Nova Acta R. Soc. Sci. Upsal. Ser. 3, 9(3): 37, 1875; Hirn in Acta Soc. Sc. Fenn. 27: 298, pl. 23, fig. 119; Prescott, Alg. Western Great Lakes Area 37 pl. 34, figs. 15, 16, 1962 (Plate 1. Fig. 4).

Description: Macrandrous, monoecious and filamentous; vegetative cell cylindric or slightly capitellate, $6.0-8.5 \mu \mathrm{m}$ broad, 23.0-30.0 $\mu \mathrm{m}$ long; oogonium single, depressed-globose; operculate; division median and narrow; 24.0-29.0 $\mu \mathrm{m}$ broad, 20.0-29.0 $\mu \mathrm{m}$ long; oospore depressedglobose; nearly filling the oogonia; oospore wall smooth; $22.5-27.0 \mu \mathrm{m}$ boad, 17.0-23.0 $\mu \mathrm{m}$ long; antheridium 7.5-9.0 $\mu \mathrm{m}$ broad, 4.0-11.0 $\mu \mathrm{m}$ long.

Habitat: Growing epiphytically on aquatic grass in a fish pond at Guptipara (Site-D).

Date of collection: 07.10.2016; Collection number: NH Oedo-03

Known distribution: India: West Bengal (Sahoo, 2006).

Outside of India: Europe: Portugal (Cambra Sánchez et al., 1998), Spain (Alvárez Cobelas and Gallardo, 1986, Cambra Sánchez et al., 1998); North America: Great Lakes (Prescott, 1962); Australia: Tasmania (Dayet al., 1995; Guiry and Guiry, 2018); and Asia: China, Bangladesh (Naz et al., 2007).

Comment: The collected specimen looks like 0 . minus Wittr. ex Hirn but differing it due to absence of spiral punctuations on wall although it possessing depressed-globose oogonium and oospore. Probably, the species is second time report from India after Sahoo 
(2006). He first time recorded 0 . gunnii var. breviarticulatum Jao from India.

5. Oedogonium khannae f. minus Gonzalves et S. C. Jain in phykos 7: 15, 1968; Gonzalves, Oedogoniales 246, fig. 9.127B, 1981 (Plate 2. Fig. 5).

Description: Plant macrandrous, heterothallic, filamentous, unbranched; light greenish; vegetative cell more or less capitellate, 6.5-7.5 $\mu \mathrm{m}$ broad and 20.0-27.5 $\mu \mathrm{m}$ long, basal cell depressed hemispherical; terminal cell apically obtuse; oogonia up to 4 and seriate, pyriform-globose, 19.5-21.0 $\mu \mathrm{m}$ broad and 17.5-23.0 $\mu \mathrm{m}$ long; operculate, division median; oospore depressed globose to slightly broader and filling the oogonium laterally, $13.0-14.0 \mu \mathrm{m}$ broad and 12.2-13.0 $\mu \mathrm{m}$ long; spore wall smooth and 3 layered, brownish and thick; antheridia not observed.

Habitat: It was grown on species of Nymphaea L. in a field pond at Khamargachi (Site-E).

Date of collection: 15.12.2016; Collection number: NH Oedo-07

Known distribution: India: Maharashtra (Gonzalves and Jain, 1968), West Bengal (Mukherjee, 1986).

Outside of India: Bangladesh in Rajshahi (Naz et al., 2009).

Comment: The described specimen is closely related in appearance with $O$. tapeinosporum Wittr. ex Hirn but differs by having larger size of vegetative cells and on the basis of other features like oogonium, oospore shape as well as oospore wall layers. Probably, the forma is second time report from West Bengal.

6. Oedogonium nanum Wittr. ex Hirn; Wittr. in Nova Acta R. Soc. Sci. Upsal. Ser. 3, 9: 37, 1874; Hirn in Acta Soc. Sci. Fenn. 27: 305, fig.174, 1900; Gonzalves in Oedogoniales 341, 1981 (Plate 2. Fig. 6).

Description: Plant macrandrous, dioecious, filamentous, slight greenish; vegetative cell often irregularly swollen; 6.0-10.0 $\mu \mathrm{m}$ broad, 15.0-33.0 $\mu \mathrm{m}$ long; chloroplast reticulate; oogonium one, ovoid to broadly ellipsoid; operculate, opening superior, 18.0-25.0 $\mu \mathrm{m}$ broad, 27.0-33.0 $\mu \mathrm{m}$ long; oospore shape same as oogonium, brownish, filling oogonium; 21.0-23.0 $\mu \mathrm{m}$ broad, 28.0-31.0 $\mu \mathrm{m}$ long; spore wall smooth; antheridia not found.

Habitat: It was epiphytic on floating hydrophyte Jussiaea repens L. in a field pond at Balarambati (Site-F).

Date of collection: 04.12.2016; Collection number: NH Oedo-06

Known distribution: India: Gujarat, Himachal Pradesh and Uttar Pradesh (Gupta, 2012); West Bengal (Sahoo, 2006).

Out side of India: North America: Great Lakes (Prescott, 1962); Asia: Iraq (Maulood et al., 2013), Bangladesh in Dhaka (Naz et al., 2007); Australia: Queensland (Phillips, 2002; Bostock and Holland, 2010) [Guiry and Guiry, 2018].

Comment: This is the second time report from West Bengal.

7. Oedogonium pratense Trans. in Amer. J. Bot. 1(6): 297, pl. 29, figs. 9-1, 1914; Prescott, Alg. Western Great Lakes Area 732, pl. 36, figs. 4, 5, 1962; Gonzalves, Oedogoniales 345, 1981 (Plate 2. Fig. 7).

Description: Plant macrandrous, dioecious and filamentous; vegetative cell cylindrical, 9.5-11.5 $\mu \mathrm{m}$ broad, 24.0$34.0 \mu \mathrm{m}$ long; oogonium solitary; globose or subpyriform-globose; operculate; division median; 42.0-44.0 $\mu \mathrm{m}$ broad, 42.0-44.0 $\mu \mathrm{m}$ long; oospore globose; not quite filling the oogonium in this specimen; wall smooth; 28.0-30.0 $\mu \mathrm{m}$ broad, 28.0-30.0 $\mu \mathrm{m}$ long; antheridia 10.0-14.5 $\mu \mathrm{m}$ broad, $13.0-17.0 \mu \mathrm{m}$ long.

Habitat: It was grown on a member of Poaceae in paddy field wetland located at Khanyan (Site-G).

Date of collection: 25.09.2016; Collection number: NH Oedo-01

Known distribution: India: Jharkhand, Karnataka and Maharashtra (Gupta, 2012); West Bengal (Sahoo, 2006).

Out side of India: North America in Great Lakes (Prescott, 1962). 
Comment: This dioecious species seems to be 0 . pratense Trans., although it possesses relatively smaller oospore and not filling the oogonium completely in female filament unlike the type species. Probably, the species is second time report from West Bengal.

8. Oedogonium rivulare A. Br. ex Hirn; A. Br. in Ber. Köngl. Akad. Wiss. Berlin 1855: 380, 1855; Hirn in Acta Soc. Sci. Fenn. 97: pl. 44, fig. 27, 1900; Prescott, Alg. Western Great Lakes Area 23, pl. 32, figs. 5, 6, 1962; Conferva rivularis L. 1753 (Plate 2. Fig. 8).

Description: Plant macrandrous, dioecious; vegetative cell cylindrical, 35.0-40.0 $\mu \mathrm{m}$ broad, 140.0-160.0 $\mu \mathrm{m}$ long; oogonium solitary (in this specimen) or 3-7 in a series; obovoidellipsoid; opening by a superior pore; 70.0-80.0 $\mu \mathrm{m}$ broad, 130.0-150.0 $\mu \mathrm{m}$ long; oospore ellipsoid or sub-globose; not filling oogonium and much smaller than oogonium; mesosore wall thick and smooth; 55.0-65.0 $\mu \mathrm{m}$ broad, 65.0-75.0 $\mu \mathrm{m}$ long; male filament cell 30.0-35.0 $\mu \mathrm{m}$ broad, 120.0-130.0 $\mu \mathrm{m}$ long; antheridium 21.0-26.0 $\mu \mathrm{m}$ broad, 14.0-25.0 $\mu \mathrm{m}$ long.

Habitat: Attached to a submerged aquatic angiospermic plant in bathing pond at Diara (Site-H).

Date of collection: 26.12.2016; Collection number: NH Oedo-08

Known distribution: India: Andaman and Nicobar Islands, Punjab (Gupta, 2012) and West Bengal (Sau and Gupta, 2005)

Out side of India: Europe: Britain (Whitton et al., 2003; John et al., 2011), Portugal (Cambra Sánchez et al., 1998); North America: Great Lakes (Prescott, 1962); South America: Argentina (Tell, 1985) [Guiry and Guiry, 2018].

Comment: This taxon seems to be somewhat similar to $O$. grande Kütz. ex Hirn on account of oogonium shape, poriferous (having pores); pore superior and spore wall smooth but it differs from the same in ellipsoid or oblong-ellipsoid oogonium, larger breadth of vegetative cell as well as size of oogonium. This species also appears to different from $O$. ellipsosporum R. N. Singh in much larger dimensions of vegetative and reproductive structures and oospores not filling oogonia as well as much smaller than oogonia. Probably this species is second time report from West Bengal.

9. Oedogonium vaucheri A. Br. ex Hirn in Acta Soc. Sci. Fenn. 97: pl. 6, fig. 36, 1900; Tiffany, The Oedogoniaceae, 76, pl. 15, figs. 150, 151, 1930; Gonzalves in Oedogoniales 187, fig. 9.56 A, 1981; Mrozinska, Chlorophyta VI. Oedogoniophyceae: Oedogoniales. In: Süßwasserflora von Mitteleuropa 73, fig. 51, 1985 (Plate 2. Fig. 9).

Description: Plant macrandrous, homothallic and filamentous; vegetative cell cylindrical, 20.0-25.0 $\mu \mathrm{m}$ broad, 30.0$35.0 \mu \mathrm{m}$ long; oogonium single, obovoid to sub-obovoid-globose, 40.0-50.0 $\mu \mathrm{m}$ broad, 45.0-55.0 $\mu \mathrm{m}$ long, poriferous, pore superior; oospore perfectly globose, brown or slight blackish, 35.0-45.0 $\mu \mathrm{m}$ broad, 35.0-45.0 $\mu \mathrm{m}$ long, not filling the oogonium; spore wall thick, smooth; antheridia up to 3 , seriate, epigynous or hypogynous, 17.0-20.0 $\mu \mathrm{m}$ broad, 6.0$14.0 \mu \mathrm{m}$ long; spermatozoids two, division horizontal (not seen in figure).

Habitat: Attached on aquatic weeds in bathing pond at Diara (Site-H).

Date of collection: 26.12.2016; Collection number: NH Oedo-09

Known distribution: India: Andhra Pradesh, Gujarat, Karnataka, Maharashtra (Gupta, 2012) and West Bengal (Mukherjee, 1986; Kargupta and Keshri, 2006; Sahoo, 2006).

Out side of India: Europe: Britain (Huxley and Pentecost, 2002; Whitton et al., 2003; John et al., 2011), Portugal (Alvárez Cobelas and Gallardo, 1986; Cambra Sánchez et al., 1998); North America: Great Lakes (Prescott, 1962); Asia: Russia (Medvedeva and Nikulina, 2014) and Bangladesh (Ahmed, 2008; Guiry and Guiry, 2018).

Comment: This species can be resembled with $O$. intermedium Wittr. 
whose filament is much smaller than this taxon. This species is also matched with 0 . fragile Wittr. in few characters like oogonium solitary; oospore is globose, pore superior but the present species is different from other taxonomic characteristics. Probably, this taxon is fourth time report from West Bengal.
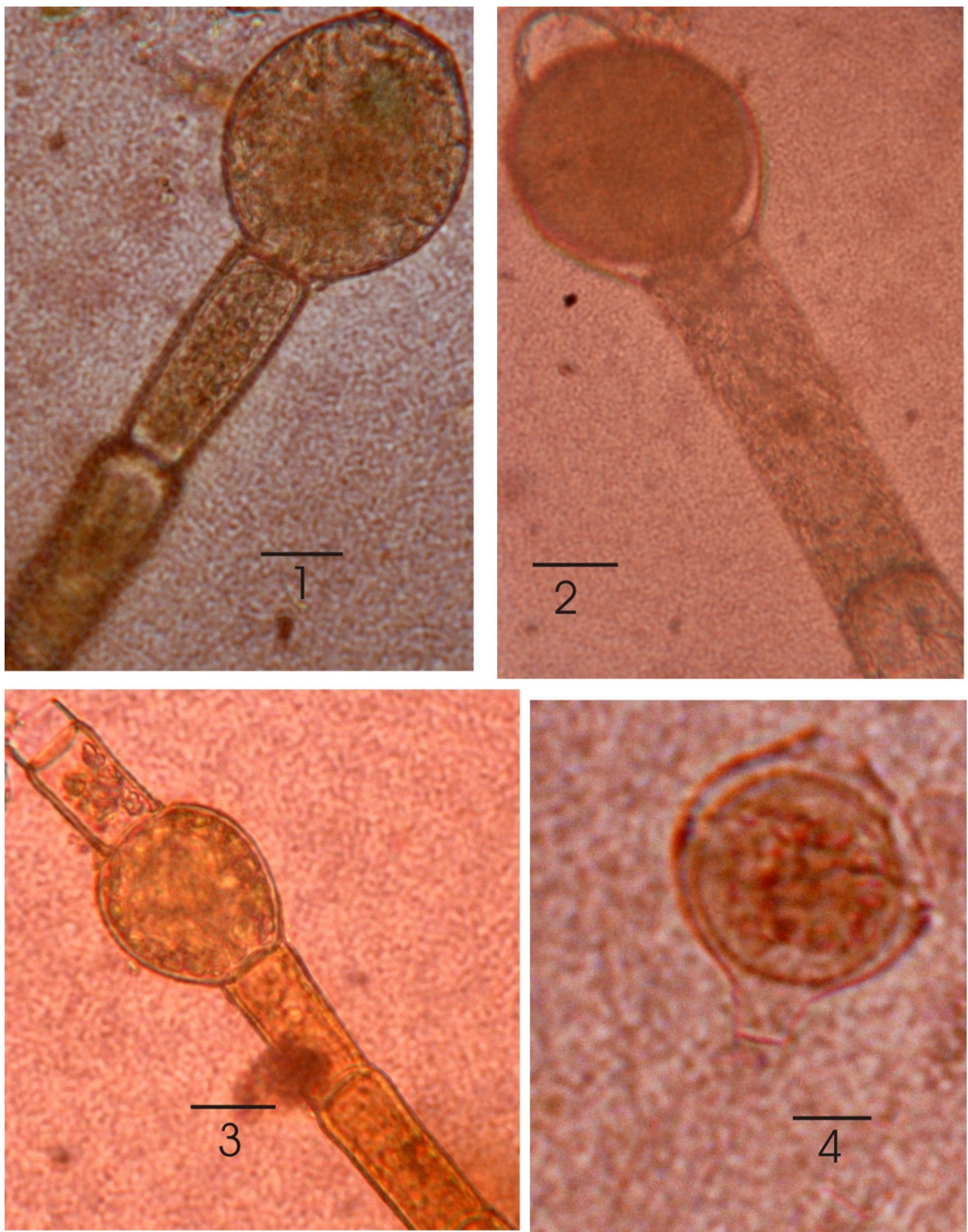

Plate 1. Figure 1. Oedogonium bharuchae Kamat. Figure 2. Oedogonium cardiacum f. pulchellum Hirn. Figure 3. Oedogonium crispum var. pyriforme (Wittr. ex Hirn) Islam et Sarma. Figure 4. Oedogonium gunnii Wittr. ex Hirn. 

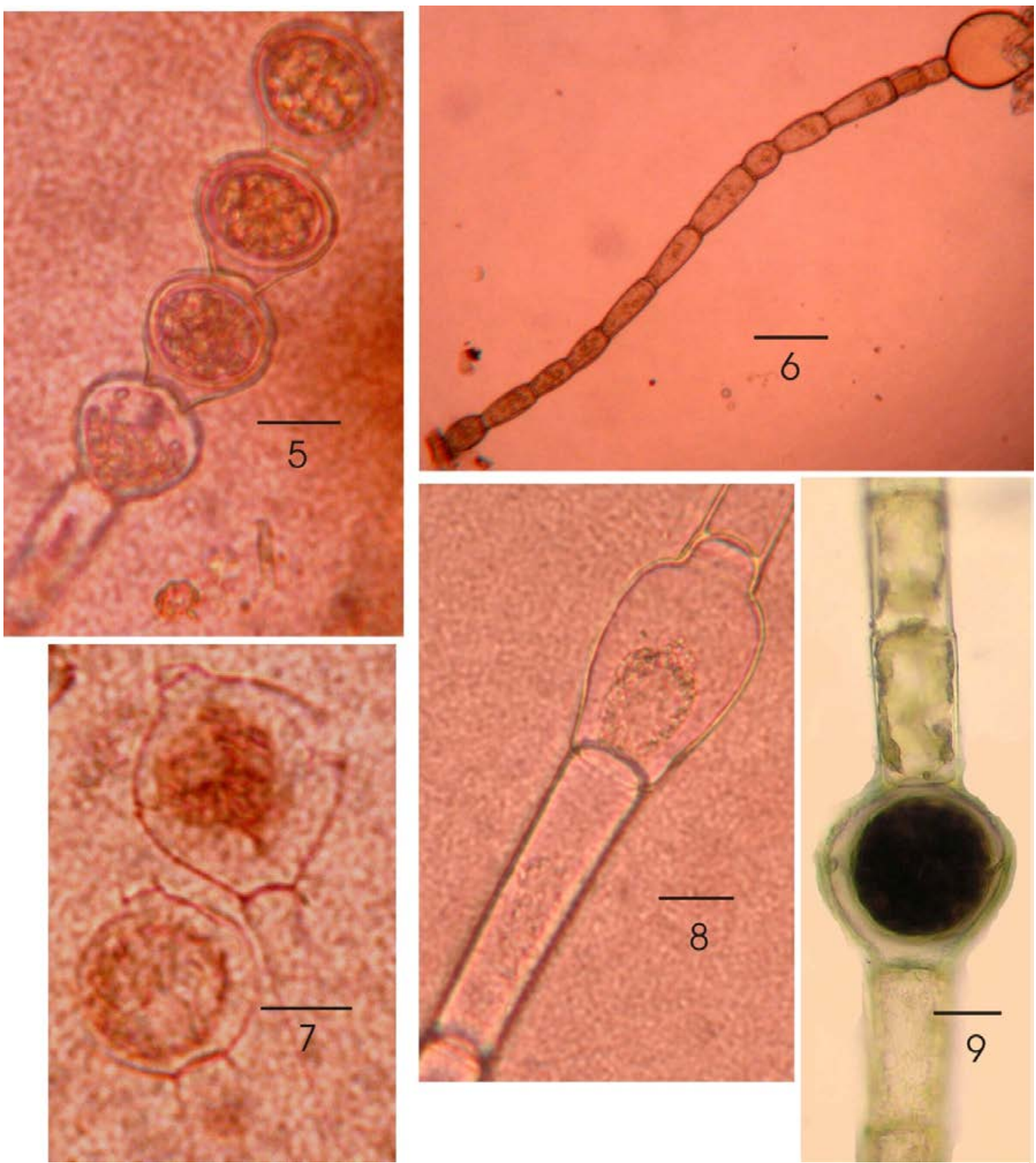

Plate 2. Figure 5. Oedogonium khannae f. minus Gonzalves et Jain. Figure 6. Oedogonium nanum Wittr. ex Hirn. Figure 7. Oedogonium pratense Trans. Figure 8. Oedogonium rivulare Br. ex Hirn. Figure 9. Oedogonium vaucheri Br. ex Hirn.

\section{Discussion}

Many species of Oedogonium can be identified by taking measurements of only filaments and oogonia. Oedogonium has been observed most frequently in natural stagnant water bodies (Pikosz and Messyasz, 2015) rather than in running water (Naz et al., 2007). Similar observation has been noticed in this study. This algal genus was found attached to the aquatic host plants 
(angiosperms) with the help of basal holdfasts throughout the vegetative and reproductive phages. The genus is exclusively epiphytic and occasionally found to grow on other algae like Cladophora Kütz. and Pithophora Wittr.

Present taxonomic study showed the biodiversity of macrandrous species of this genus. All the fertile documented species had been collected after withdrawal of monsoon i.e. from postmonsoon to winter (from last week of September to December, 2016). In vegetative condition, filaments appeared greenish but when achieved maturity they became brownish mostly.

In ecological study, assessment of water quality is considered as an essential criterion because the flourish as well as periodicity of algae in aquatic ecosystem is basically dependent on seasonal variations of physico-chemical characteristics (water quality) and adaptive nature of algal species. The result obtained from physico-chemical analysis of all water samples is given below (Table 2). Water temperature is considered as one of the most important factors of the aquatic environment and it affects directly the growth rate of algae (Halder, 2016b). It varies with changes of season, elevation and geographic location. During the experimental period, maximum and minimum water temperature were recorded at site $\mathrm{G}$ $\left(20^{\circ} \mathrm{C}\right)$ and site $\mathrm{H}\left(17.5^{\circ} \mathrm{C}\right)$. In this work, temperature was also showed a considerable negative correlation with DO. $\mathrm{pH}$ is a measure of the amount of free hydrogen ions present in water. Specifically, it is the negative logarithm of the concentration of hydrogen ions. It indicates the acid base balance of the water. A pH of greater 7.0 is considered to be alkaline. $\mathrm{pH}$ was noticed highest at site $H$ (7.6) in December during winter and minimum at site $G$ (7.1) in September (post-monsoon), 2016. The $\mathrm{pH}$ range is quite similar with the previous result of water analysis (Sinha and Halder, 2014; Halder, 2016c). In addition to this, $\mathrm{pH}$ was found slight alkaline due to richness of algal flora and hardness of water. There had been found a direct positive correlation between $\mathrm{pH}$ and total hardness while negative correlation between two indicative variables- $\mathrm{pH}$ and free $\mathrm{CO}_{2}$. Dissolved oxygen (D0), one of the most important parameters to assess water quality, affects the survival, distribution, growth and physiology of aquatic organisms. In this investigation, it was noted higher (6.4 mg. $\mathrm{L}^{-1}$ or above) in all the study sites that indicated low pollution level and high productivity rate. It was observed high due to well wind action, abundance of vegetation or accelerated photosynthetic activity by green plants and lower respiratory effects by zooplanktons, fishes or other aquatic animals into those water bodies. BOD is the amount of dissolved oxygen required by aerobic biological organisms like bacteria for breakdown of organic compounds (Halder, 2017b) and it is an indicator parameter of pollution present in aquatic ecosystems. The BOD values were found moderate in all the water bodies (sites A to $\mathrm{H}$ ) which denoted presence of pollution. In this study, it was varied between 10.0 and 18.0 mg.L $\mathrm{L}^{-1}$. It also showed negative correlation with DO content. COD represents oxygen requirements to oxidize organic and inorganic matters in water sample and release $\mathrm{CO}_{2}$ and water. $\mathrm{COD}$ values are always greater than BOD values. In all the sites, COD values also appear moderate that reflects presence of domestic sewages and decaying materials or death flora/fauna in the algal habitats. This is also an indication of water pollution. In this study, COD was 2.5 to 3 times higher than BOD. It was ranged from $24.0-44.0 \mathrm{mg} . \mathrm{L}^{-1}$. Nutrients (such as $\mathrm{NO}_{3}-\mathrm{N}$ and $\mathrm{PO}_{4}{ }^{3-}$ ) act as limiting factors for growth of algae and other plants. Excessive concentrations of nutrients can produce algal bloom. However, nitrate-nitrogen $\left(\mathrm{NO}_{3}-\mathrm{N}\right)$ was found low due to it's fairly utilization by algae and other hydrophytes (green vegetation) during photosynthesis. 
Similarly, phosphate $\left(\mathrm{PO}_{4}^{3-}\right)$ was present in very small quantity in water although it is important for the production of phytoplanktons and other algal forms. They were ranged from $0.60-0.75 \mathrm{mg} . \mathrm{L}^{-1}$ and 0.50-0.62 mg. $\mathrm{L}^{-1}$, respectively. In site-G (paddy field wetland) both the nutrient contents were highest followed by A (agricultural pond) that might be due to contamination of fertilizer or agricultural run-off in water. Chloride ( $\mathrm{Cl}-$ ) is a common component of most waters. The concentration of $\mathrm{Cl}^{-}$ particularly, depends on water level. It has been observed that when water level becomes decrease, then $\mathrm{Cl}$ - level is found to increase. In summer, therefore, its concentration is observed normally high. In this investigation, this value was low because water samples were collected after monsoon that consequently made the dilutions of water samples several times. It was ranged from 5.5-6.5 mg.L-1 Free carbon dioxide $\left(\mathrm{CO}_{2}\right)$ which is evolved by the respiratory activities of aquatic animals and exists in water as bicarbonate or carbonates is a highly soluble gas found in water. It was noted lowest in December during winter at site- $\mathrm{H}\left(8.0 \mathrm{mg} . \mathrm{L}^{-1}\right)$ due to less decaying of organic matters. In most of the limnological studies, it is observed higher in summer due to its reverse phenomenon. In this Table 2 , free $\mathrm{CO}_{2}$ has been found inversely proportional to $\mathrm{pH}$ value. TDS is a measure of combined contents of organic and inorganic substances present in water as suspended forms. It was found low in all the sites. It was ranged from 140.4-218.0 mg. $\mathrm{L}^{-1}$. Normally, this value is found greater in monsoon as the rain brings soluble salts, silts, clay and suspensoids in water bodies. After withdrawal of monsoon they are become settled down slowly at bottom of water reservoirs. Probably, for this reason TDS values were observed low in amounts ( $\left.\leq 500 \mathrm{mg} \cdot \mathrm{L}^{-1}\right)$. Total hardness $(\mathrm{TH})$ is a chemical parameter of water that represents mainly the total concentration of divalent cations of calcium and magnesium. Thus, hard water contains a lot of dissolved minerals. On the basis of the degree of hardness as developed by the water quality association, all the studied water samples fall in the hard water category which was ranged from 120.0-204.0 mg. $\mathrm{L}^{-1}$. There has been a close relationship between $\mathrm{pH}$ and total hardness. Hard water is usually with high $\mathrm{pH}$ content. Turbidity is the ability of water to transmit the light that restricts light penetration due to presence of suspended clay particles, planktons or particular organic matters. This value of water was noted less $(<10.0 \mathrm{NTU})$ in all the study sites. It was varied from 6.8-9.0 NTU.

It has been clearly observed from this ecological study that water quality is variable in different sites as well as over the changes of months due to chemical, physical and biological factors. In addition to that water samples could be classified as less turbid water. Thus, in the above investigation only DO and total hardness were found higher and other parameters found within low to medium range. Depending upon the analysis of water, it could be concluded that all the aquatic habitats (sites A-H) were less polluted and mesotrophic in pollution status. Therefore, this algal genus may be used as an ecological indicator to depict the pollution level and trophic status. More or less similar trends were revealed in other algological studies in Hooghly (Halder, 2015b; Halder, 2016d). 
Table 2. Physico-chemical characteristics of waters in the eight collection sites in Hooghly.

\begin{tabular}{|c|c|c|c|c|c|c|c|c|c|}
\hline & $\begin{array}{l}\text { Physico- } \\
\text { Chemical } \\
\text { features }\end{array}$ & Site-A & Site-B & Site-C & Site-D & Site-E & Site-F & Site-G & Site-H \\
\hline 1 & Temp. $\left({ }^{\circ} \mathrm{C}\right)$ & $19.5 \pm 0.1$ & $18.5 \pm 0.2$ & $18.0 \pm 0.2$ & $19.5 \pm 0.22$ & $18.0 \pm 0.24$ & $18.5 \pm 0.2$ & $20.0 \pm 0.22$ & $17.5 \pm 0.24$ \\
\hline 2 & $\mathrm{pH}$ & $7.2 \pm 0.05$ & $7.3 \pm 0.05$ & $7.3 \pm 0.04$ & $7.2 \pm 0.05$ & $7.4 \pm 0.05$ & $7.4 \pm 0.05$ & $7.1 \pm 0.05$ & $7.6 \pm 0.05$ \\
\hline 3 & DO (mg. $\left.\mathrm{L}^{-1}\right)$ & $6.4 \pm 0.1$ & $6.6 \pm 0.1$ & $6.5 \pm 0.06$ & $6.5 \pm 0.08$ & $7.0 \pm 0.1$ & $6.8 \pm 0.1$ & $6.4 \pm 0.06$ & $7.2 \pm 0.08$ \\
\hline 4 & BOD (mg.L $\left.\mathrm{L}^{-1}\right)$ & $15 \pm 0.05$ & $14.0 \pm 0.06$ & $14.0 \pm 0.08$ & $15.0 \pm 0.1$ & $12.0 \pm 0.08$ & $13.0 \pm 0.06$ & $18.0 \pm 0.1$ & $10.0 \pm 0.05$ \\
\hline 5 & COD (mg.L $\left.{ }^{-1}\right)$ & $36.0 \pm 0.5$ & $35.0 \pm 0.5$ & $34.0 \pm 1.1$ & $38.0 \pm 0.8$ & $30.0 \pm 0.6$ & $32.0 \pm 1.1$ & $44.0 \pm 0.5$ & $24.0 \pm 1.1$ \\
\hline 6 & $\mathrm{NO}_{3}-\mathrm{N}\left(\mathrm{mg} \cdot \mathrm{L}^{-1}\right)$ & $0.70 \pm 0.05$ & $0.62 \pm 0.05$ & $0.65 \pm 0.06$ & $0.65 \pm 0.05$ & $0.60 \pm 0.05$ & $0.62 \pm 0.05$ & $0.75 \pm 0.05$ & $0.67 \pm 0.05$ \\
\hline 7 & $\mathrm{PO}_{4}^{3-}$ mg.L-1 & $0.60 \pm 0.06$ & $0.56 \pm 0.06$ & $0.54 \pm 0.07$ & $0.58 \pm 0.07$ & $0.50 \pm 0.06$ & $0.54 \pm 0.05$ & $0.62 \pm 0.06$ & $0.50 \pm 0.05$ \\
\hline 8 & $\mathrm{Cl}^{-}\left(\mathrm{mg} . \mathrm{L}^{-1}\right)$ & $6.2 \pm 0.05$ & $6.0 \pm 0.1$ & $6.0 \pm 0.05$ & $5.8 \pm 0.05$ & $6.0 \pm 0.05$ & $6.0 \pm 0.05$ & $5.5 \pm 0.05$ & $6.5 \pm 0.05$ \\
\hline 9 & Free $\mathrm{CO}_{2}\left(\mathrm{mg} . \mathrm{L}^{-1}\right)$ & $10.0 \pm 0.2$ & $16.0 \pm 0.2$ & $18.0 \pm 0.2$ & $12.0 \pm 0.2$ & $20.0 \pm 0.2$ & $22.0 \pm 0.2$ & $24.0 \pm 0.2$ & $8.0 \pm 0.1$ \\
\hline 10 & TDS (mg.L $\left.{ }^{-1}\right)$ & $150.6 \pm 1.1$ & $168.4 \pm 1.1$ & $175.8 \pm 0.5$ & $218.0 \pm 0.5$ & $158.8 \pm 0.5$ & $176.2 \pm 0.5$ & $182.0 \pm 0.5$ & $140.4 \pm 1.1$ \\
\hline 11 & TH (mg.L $\left.\mathrm{L}^{-1}\right)$ & $128.0 \pm 1.1$ & $132.0 \pm 1.1$ & $138.0 \pm 1.1$ & $124.0 \pm 1.1$ & $148.0 \pm 1.1$ & $152.0 \pm 1.1$ & $120.0 \pm 1.1$ & $204.0 \pm 1.1$ \\
\hline 12 & Turb. (mg.L-1) & $7.2 \pm 0.11$ & $7.6 \pm 0.11$ & $8.0 \pm 0.1$ & $8.2 \pm 0.1$ & $7.0 \pm 0.11$ & $7.2 \pm 0.1$ & $6.8 \pm 0.12$ & $9.0 \pm 0.1$ \\
\hline
\end{tabular}

Values are Mean \pm SEM; Temp. $=$ Temperature, DO = Dissolved oxygen, BOD = Biological oxygen demand, COD $=$ Chemical oxygen demand, $\mathrm{NO}_{3}-\mathrm{N}=$ Nitrate-nitrogen, $\mathrm{PO}_{4}{ }^{3-}=$ Phosphate, $\mathrm{Cl}^{-}=$Chloride, Free $\mathrm{CO}_{2}=$ Free Carbon-dioxide, $\mathrm{TH}=$ Total hardness as $\mathrm{CaCO}_{3}$, Turb. $=$ Turbidity.

\section{Conclusion}

In this study, biodiversity, distribution and ecology of the genus had been discussed elaborately and overall nine taxa of this genus were identified from the Class Chlorophyceae. It had been observed that hydrological condition of water affected the occurrence, growth and diversity of this alga and filaments with reproductive structures were noticed maximum in winter perhaps, this season along with seasonal changes of water quality supported the formation of fruiting structures in the vegetative filaments. The ecological conditions especially, alkaline $\mathrm{pH}$, low turbidity and hardness of water were noted most effective for their occurrence.

\section{Conflict of interest statement}

Author declares that they have no conflict of interests.

\section{References}

Adesalu, T. A.; Temenu, T. O.; Julius, M. L. Molecular characterization, lipid analysis and GC-MS determination of bioactive compounds identified in a West African strain of the green alga Oedogonium (Chlorophyta). Journal of Pharmacognosy and Phytochemistry, v. 5, p. 1-6, 2016. Available from: <http://www.phytojournal. com/archives/2016/vol5issue6/PartA/5-543-408.pdf>. Accessed on: May 09, 2018.

Ahmed, Z. U. (Ed.). Encyclopedia of flora and fauna of Bangladesh. Dhaka: Asiatic Society of Bangladesh, 2008. (v. 3. Algae, Chlorophyta).

Alvárez Cobelas, M.; Gallardo, T. Catálogo de las algas continentales españolas. IV. Chlorophyceae Wille in Warming 1884. Prasinophyceae Christensen ex Silva 1980. Acta Botanica Malacitana, v. 11, p. 17-38, 1986. Available from: <https://riuma.uma. es/xmlui/handle/10630/3611>. Accessed on: May 09, 2018.

Anand, V. K.; Jitendra, P. Studies on species diversity and ecology of genus Oedogonium Link occurring in aquatics of Shivalik Himalayas of Jammu. Journal of Phytological Research, v. 19, p. 245-250, 2006. Available from: <http://www. jphytolres.org/system/files/old_papers/chap ter\%2017_6.pdf>. Accessed on: May 09, 2018.

APHA - American Public Health Association. Standard method for the examination of water and waste waters. 21.ed. Washington, DC: APHA, AWWA, WEF, 2005.

Asthekar, P. V.; Kamat, N. D. Oedogoniaceae and Zygnemataceae of Aurangabad, Maharashtra. Phykos, v. 17, p. 35-38, 1978.

Bharadwaja, Y. The freshwater algae of Manipur, India. Proceeding of the Indian 
Academy of Sciences, Section B, v. 57, p. 239-258, 1963.

Bharati, S. G.; Pai, K. M. On the occurrence of some Oedogoniaceae in certain soil of Mysore state. Journal of the Karnataka University, v. 17, p. $132-139,1972$.

Bostock, P. D.; Holland, A. E. Census of the Queensland Flora. Brisbane: Queensland Herbarium Biodiversity and Ecosystem Sciences, Department of Environment and Resource Management, 2010.

Brouard, J. S.; Otis, C.; Lemieux, C.; Turmel, M. Chloroplast DNA sequence of the green alga Oedogonium cardiacum (Chlorophyceae): Unique genome architecture, derived characters shared with the Chaetophorales and novel genes acquired through horizontal transfer. BMC Genomics, 9:290, 2008. https://doi.org/10.1186/1471-2164-9-290

Cambra, J.; Aboal, M. Filamentous green algae of Spain: distribution and ecology. Limnetica, v. 8, p. 213-220, 1992. Avalibale from: <http://www.limnetica.com/ documentos/limnetica/limnetica-8-1-p213.pdf>. Accessed on: May 09, 2018.

Cambra Sánchez, J.; Alvárez Cobelas, M.; Aboal, M. Lista florística y bibliográfica de los clorófitos (Chlorophyta) de la Península Ibérica, Islas Baleares e Islas Canarias. Burgos: Asociación Española de Limnología, 1998.

Day, S. A.; Wickham, R. P.; Entwisle, T. J.; Tyler, P. A. Bibliographic check-list of nonmarine algae in Australia. Canberra: Australian Biological Resources Study, 1995. (Flora of Australia Supplementary Series 1323-2169, no. 4).

Dhande, J. S.; Jawale, A. K. On Oedogonium (Link) Hirn from Jalgaon District, Maharashtra. Geobios, v. 33, p. 321-322, 2006.

Fritsch, F.E. The structure and reproduction of the algae. London: Cambridge University Press, 1935. v. 1.

Gonzalves, E. A.; Jain, S. C. Some Oedogoniaceae from Tungar Hill and surroundings. Phykos, v. 7, p. 9-22, 1968.

Gonzalves, E. A.; Jain, S.C. Some Oedogoniaceae from Thana District. Phykos, v. 9, p. 1-16, 1970.

Gonzalves, E. A.; Sonnad, G. R. The genus Oedogonium in Mysore state. Journal of Bombay Natural History Society, v. 58, p. $715-723,1961$.
Gonzalves, E. A. Oedogoniales. New Delhi, India: ICAR, 1981.

Goyal, S. K. Algal flora of Jodhpur and its environs. III. Oedogoniales. Journal of Bombay Natural History Society, v. 61, p. 385-395, 1964.

Guiry, M. D.; Guiry, G. M. AlgaeBase. Worldwide electronic publication, National University of Ireland, Galway, 2018. Available from: <http://www.algaebase.org>. Accessed on: May 09, 2018.

Gupta, A. B. A contribution to the algal flora of khajnar Champa state, Himachal Pradesh. Proceeding of the Natural Academy of Sciences of India, v. 20, p. 109-115, 1950.

Gupta, R. K. Algae of India. Salt Lake, Kolkata: Botanical Survey of India, Ministry of Environment and Forests, 2012. (v. 2. A checklist of Chlorophyceae, Xanthophyceae. Chrysophyceae and Euglenophyceae).

Habib, I.; Pandey, U. C. Oedogoniales of Nakatia River, Bareilly, Uttar Pradesh, India. Advances in Plant Sciences, v. 3, p. 136-140, 1990.

Halder, N.; Sinha, S. N. New report of the occurrence of four chlorophycean algal species from West Bengal, India. Journal of Algal Biomass Utilization, v. 6, p. 20-23, 2015. Available from: <http://jalgalbiomass. com/paper4vol6no3.pdf>. Accessed on: May 09, 2018.

Halder, N.; Sinha, S. N. Nitella flagelliformis A. Br. and Chara braunii Gm.: Two new records of Charophytes from fresh water bodies in Hooghly District, West Bengal, India. Tropical Plant Research, v. 3, p. 354-360, 2016. Available from: <http://www.tropical plantresearch.com/archives/2016/vol3issue 2/14.pdf>. Accessed on: May 09, 2018.

Halder, N. Observation of taxonomic features of a terrestrial algae Oedocladium terrestre Biswas (chlorophyceae) with soil analysis from West Bengal, India. Journal Natural History Museum, v. 29, p.1-8, 2015a. https://doi.org/10.3126/jnhm.v29i0.19033

Halder, N. Taxonomical studies of three species of an epiphytic alga Coleochaete Bréb. with ecological notes in West Bengal, India. Our Nature, v. 13, no. 1, p. 19-25, 2015 b. https://doi.org/10.3126/on.v13i1.14204

Halder, N. On the occurrence of Johannesbaptisia pellucida (Dickie) W.R. Taylor et Drouet from freshwater habitat in West Bengal, India. Current Life Science, 
v. 2, p. 79-85, 2016a. Available from: <http://newjournals.tmkarpinski.com/index. php/cls/article/view/460/237>. Accessed on: May 09, 2018.

Halder, N. Impact of nutrients on distribution of Micrasterias sp. in Hooghly Province, West Bengal, India. International Journal of Environment, v. 5, no. 2, p. 36-47, 2016b. https://doi.org/10.3126/ije.v5i2.15004

Halder, N. Two algal species of Volvox L. with their taxonomy and ecology from West Bengal, India. Songklanakarin Journal of Science and Technology, v. 38, no. 4, p. 435-437, 2016c. Available from: <http://rdo.psu.ac.th/sjstweb/journal/384/38-4-13.pdf>. Accessed on: May 09, 2018.

Halder, N. Assessment of physico-chemical properties of pond water in relation to seasonal changes of algal floral composition at Balagarh, Hooghly in West Bengal, India. Climate Change, v. 2, p. 274-282, $2016 \mathrm{~d}$. Available from: <http://www.discovery journals.org/climate_change/current_issue/v 2/n8/A3.pdf>. Accessed on: May. 09, 2018.

Halder, N. Taxonomy and biodiversity of the genus Oscillatoria Vauch. ex Gom. (Cyanoprokaryota: Oscillatoriales) with ecological notes from Hooghly in West Bengal, India. Brazilian Journal of Biological Sciences, v. 4, no. 7, p. 89-101, 2017a. https://doi.org/10.21472/ bjbs.040710

Halder, N. Notes on two species of Zygnema C. Ag. with water analysis from Hooghly in West Bengal, India. Current Life Sciences, v. 3, no. 1, p. 6-14, 2017b. Available from: <http://newjournals.tmkarpinski.com/index. $\mathrm{php} / \mathrm{cls} /$ article/view/583/273>. Accessed on: May. 09, 2018.

Hirn, K. E. Monographie und Iconographie der Oedogoniaceen. Acta Societatis Scientiarum Fennica, v. 27, p. 1-394, 1900.

Huxley, R.; Pentecost, A. Order Oedogoniales. In: John, D. M.; Whitton, B. A.; Brook, A. J. (Ed.). The Freshwater Algal Flora of the British Isles. An identification guide to freshwater and terrestrial algae. Cambridge: Cambridge University Press, 2002. p. 409-432.

Islam, A. K. M. N.; Sarma, P. Freshwater algae of Bangladesh. V. Genus Oedogonium. Nova Hedwigia, v. 27, p. 425-454, 1976.

Jitendra, P.; Anand, V. K. Eight new records of fresh water filamentous algae (Oedogonium Link) from India. Tropical Plant Research, v. 3, no. 1, p. 33-39, 2016. Available from: <http://www.tropicalplantresearch.com/arc hives/2016/vol3issue1/4.pdf>. Accessed on: May. 09, 2018.

John, D. M.; Whitton, B. A.; Brook, A. J. (Ed.). The freshwater algal flora of the British Isles. An identification guide to freshwater and terrestrial algae. 2.ed. Cambridge: Cambridge University Press, 2011.

Kamat, N. D. Two new Oedogonium from India. Rev. Algol., v. 6, p. 217-219, 1962.

Kamat, N. D. The Algae of Mount Abu. Proceeding of Royal Academy of Science, v. 11 , p. 49-54, 1967.

Kamat, N. D. Algae of Simla. Journal of Bombay Natural History Society, v. 65, p. 271-277, 1968.

Kamat, N. D. Algae of Marathwada, Maharastra. Phykos, v. 13, p. 22-32, 1974.

Kamat, N. D. Algae of Vidarbh, Maharashtra. Journal of Bombay Natural History Society, v. 72, p. 450-476, 1976.

Kargupta, A. N.; Keshri, J. P. New record of macrandrous Oedogonium (Oedogonilaes, Chlorophyceae) taxa from West Bengal, India. Algological Studies/Archiv für Hydrobiologie, Supplement Volumes, No. 122 , p. 57-71, 2006. https://doi.org/ 10.1127/1864-1318/2006/0122-0057

Keshri, J. P. The genus Oedogonium Link (Chlorophyta: Oedogoniales) in West Bengal, India. Sttutgart: J. Cramer, 2012. (Bibliotheca Phycologica, 117).

Khan, M. Algal of Sultanpur (U. P.), India. Phykos, v. 24, p. 52-57, 1985.

Laksminarayana, S.S. Observations on aquatic algal flora of high altitudes. Proceeding of the Symposium of Water Supply, Waste and Disposal, Nagpur, India, CPHERI, p. 49-57, 1965.

Lawton, R. J.; De Nys, R.; Skinner, S.; Paul, N. A. Isolation and identification of Oedogonium species and strains for biomass applications. PLoS One, v. 9, no. 5, e90223, 2014. https://doi.org/10.1371/journal.pone.00902 23

Mahato, A. K. A new species of Oedogonium (Chlorophyceae, Oedogoniales) from Bihar, India. Feddes Repertorium, v. 110, no. 3/4, p. 173-176, 1999. https://doi.org/10.1002/ fedr.19991100304

Mahato, A. K.; Das, R. N.; Mahato, P. Macrandrous dioecious species of the genus 
Oedogonium (Oedogoniales, Chorophyceae) from South Bihar, India. In: Vidyavati and Mahato, A. K. (Ed.). Recent trends in algal taxonomy. New Delhi, India: Associate Publishing Co., p. 375-389, 2006. (v. 2. Taxonomical and Cultural Studies).

Mahato, P.; Mahato, A. K. Three setiferous species of Oedogonium from Jharkhand, India. Phykos, v. 39, p. 1-6, 2000.

Maulood, B. K.; Hassan, F. M.; Al-Lami, A. A.; Toma, J. J.; Ismail, A. M. Checklist of algal flora in Iraq. Baghdad, Iraq: Ministry of Environment, 2013.

Medvedeva, L. A.; Nikulina, T. V. Catalogue of freshwater algae of the Southern part of the Russian Far East. Vladivostok: Dalnauka, 2014.

Misra, P. K.; Srivastava, A. K.; Mehrotra, R. K.; Singh, S. K. Genus Oedogonium Link in Northeastern Uttar Pradesh. Geophytology, v. 30, p. 103-109, 2002.

Mukherjee, D. D. Study of the Oedogoniales. West Bengal, India: University of Burdwan, 1986. (Ph. D. thesis).

Munir, N.; Imtiaz, A.; Sharif, N.; Naz, S. Optimization of growth conditions of different algal strains and determination of their lipid contents. Journal of Animal \& Plant Sciences, v. 25, p. 546-553, 2015. Available from: <http://www.thejaps.org.pk/ docs/v-25-03/18.pdf>. Accessed on: May 09, 2018.

Naz, S.; Nahar, U.; Zaman, M.; Azam, S. M. G. G. Reports on epiphytic species of Oedogonium from Bangladesh. Plant Environ. Dev., v. 1, p. 45-51, 2007.

Naz, S.; Nahar, U.; Ali, M. S.; Azam, S. M. G. G. New records of Oedogonium Link in Nees from Rajshahi District, Bangladesh. Bangladesh J. Bot., v. 38, p. 27-31, 2009.

Novis, P.M.A taxonomic survey of Oedogonium (Oedogoniales, Chlorophyta) in the South Island and Chatham Islands, New Zealand. New Zealand J. Bot., v. 41, p. 335358, 2003.

Pandey, D. C. A study of Algae from Paddy fields soils of Ballia and Gazipur Districts of Uttar Pradesh, India. Part I. Nova Hedwigia, v. 9, p. 299-334, 1965.

Parukutty, P. R. On a collection of algae from Assam. Proc. Indian Acad. Sci. B., v. 9, p. 229-235, 1939.
Patel, R. J. Contribution to Oedogonilaes (Chlorophyceae) Gujrat (India). J. Phytol. Res., v. 3, p. 119-122, 1990.

Patil, S. A.; Chaudhari, N. A.; Kumawat, D. A.; Jawale, A. K. Contribution to the knowledge of Oedogoniales from Jalgaon District, Maharshtra. Int. J. Innovative Res. Rev., v. 3, p. 30-36, 2015.

Pérez Gutiérrez, R. M.; Vargas Solis, R.; Martínez Martínez, F.; Garcia Baez, E.; Figueroa Torres, G. $\delta$-Lactone from Oedogonium capillare and their effects on rat ileum. Nat. Prod. Res., v. 20, p. 305-310, 2006.

Phadnis, S.; Iyer, G. Biodiversity of the genus Oedogonium Link ex Hirn 1900 in Raigad District, Maharashtra, India. Int. J. Life Sci., v. 4, p. 214-226, 2016.

Phillips, J. A. Algae. In: R. J. F. Henderson (Ed.). Names and distribution of Queensland plants, algae and lichens. Brisbane: Queensland Government Environmental Protection Agency, 2002. p. 228-244.

Pikosz, M.; Messyasz, B. Composition and seasonal changes in filamentous algae in floating mats. Oceanol. Hydrobiol. Stud., v. 44, p. 273-281, 2015.

Prescott, G. W. Algae of the Western Great Lakes Area. 2. ed. Dubuque, Iowa: W.M.C. Brown Com., 1962.

Saha, L. C. Ulotrichales, Cladophorales, Chaetophorales, and Oedogoniales of Bhagalpur, India. Journal of Economic and Taxonomic Botany, v. 7, p. 676-679, 1985.

Sahoo, S. K. A study on the microbial diversity of agricultural land of Sagar Island (Sundarbans, W. B.) with special reference to algae. West Bengal, India: University of Burdwan, 2006. (Ph. D. thesis).

Sahoo, S. K.; Datta, B. K.; Sarma, P. New records of the genus Oedogonium (Oedogoniales: Chlorophyceae) from West Bengal, India. Algological Studies, v. 144, p. 3-17, 2014. https://doi.org/10.1127/ 1864-1318/2014/0107

Sau, A.; Gupta, R. K. Algal flora of Indian botanic garden, Howrah, West Bengal. Nelumbo - Bulletin of the Botanical Survey of India, $\quad$ v. $47, \quad$ p. 63-86, 2005. https://doi.org/10.20324/nelumbo/v47/20 $05 / 74110$ 
Seal, T.; Halder, N.; Chaudhuri, K.; Sinha, S. N. Effect of solvent extraction system on the antioxidant activities of algae. International Journal of Pharmacy and Pharmaceutical Sciences, v. 6, p. 242-245, 2014.

Singh, R. N. The Oedogoniales of the United Provinces, India I. Proceeding of Indian Academy Sciences, Sector B, v. 8, p. 373395, 1938.

Sinha, S. N.; Halder, N. New report of Dichotomosiphon tuberosus (A.Br.) Ernst and Vaucheria sessilis D.C. of the Family Vaucheriaceae from Hooghly District, West Bengal, India. Ecoprint, v. 21, p. 49-53, 2014. https://doi.org/10.3126/eco.v21i0.11904

Sinha, S. N.; Biswas, K.; Paul, D.; Halder, N. Taxonomic study of Enteromorpha compressa (L.) Nees (Ulvales, Chlorophyceae) in West Bengal, India. Journal Algal Biomass Utilization, v. 7, p. 53-57, 2016. Available from: <http://jalgalbiomass.com/paper6 vol7no3.pdf>. Accessed on: May 09, 2018.

Snehalatha, D.; Rao, D. B. Antifungal activity of freshwater green-algae (Chlorophyceae). European Journal of Pharmaceutical and Medical Research, v. 2, p. 1394-1402, 2015. Available from: <http://www.ejpmr.com/ admin/assets/article_issue/1442828086.pdf >. Accessed on: May 09, 2018.

Subba Raju, N. Oedogoniaceae from Andhra Pradesh. I. The genus Oedogonium. Journal of Osmania University, Golden Jubilee vol., p. 161-177, 1968.

Tell, G. Catálogo de las algas de agua dulce de la República Argentina. Sttutgart: J. Cramer, 1985. (Bibliotheca Phycologica, 70).

Tonetto, A. F.; Oliveira, K. S. M.; Domingues, T. M. Analysis of biochemical composition of three stream macroalgae species. Int. J. Appl. Sci. Technol., v. 4, p. 111-115, 2014.

Venkataraman, G. S.; Natarajan, K. V. Notes on some Oedogoniales from Kerala State, India. Proceeding of the Natural Institute of Science, v. 26, p. 7-18, 1960.

Venkataraman, G. S. Some new and interesting forms of Oedogonium from Uttar Pradesh. Journal of Bombay Natural History Society, v. 56, p. 60-65, 1959.

Wehr, J. D.; Sheath, R. G.; Kociolek, J. P. Freshwater Algae of North America: Ecology and Classification (Aquatic Ecology). 2. ed. San Diego: Academic Press, 2015.

Whitton, B. A.; John, D. M.; Kelly, M. G.; Haworth, E. Y. A coded list of freshwater algae of the British Isles. 2. ed. World-wide Web electronic publication, 2003. Available from: <http://www.ceh.ac.uk/data/dict/ algae/index.htm>. Accessed on: May 09, 2018.

Yadava, A. K.; Bharadwaja, T. N. Freshwater algae of Ajmer and Kishengarh, Rajasthan, India. Nova Hedwigia, v. 63, p. 67-103, 1979.

License information: This is an open-access article distributed under the terms of the Creative Commons Attribution License, which permits unrestricted use, distribution, and reproduction in any medium, provided the original work is properly cited. 